\title{
Comparative study of seed yield and seed quality of advanced lines and commercial varieties of red clover (Trifolium pratense $\mathrm{L}$.)
}

\author{
Borislav Petkovic $^{1 *}$, Novo Przulj,4, Vojo Radic ${ }^{2}$, Milan Mirosavljevic ${ }^{3}$ \\ Faculty of Agriculture, University of Banja Luka, \\ Bosnia and Herzegovina. \\ Received: 10-04-2017 \\ Accepted: 07-07-2017 \\ DOI: $10.18805 / \mathrm{LR}-360$
}

\section{ABSTRACT}

Red clover (Trifolium pratense L.) is one of the most important forage legumes in areas with acidic and nutrient poorer soils where alfalfa fails to growth. In 2010-2011 years period we studied four advanced lines and four commercial varieties of red clover, which are widely used in the production in Bosnia and Herzegovina. Our results showed that the variation in grain yield, thousand kernel weight and germination energy was under control of growth. Across genotypes seed yield in 2010 and 2011 was 205 and $223 \mathrm{~kg} \mathrm{ha}^{-1}$, respectively. The highest yield of seed was obtained from second growth in the second year. Extreme precipitation during anthesis and grain filling and ripening in 2010 negatively affected red clover seed production. Advanced line DS-2 had the highest grain yield $\left(234 \mathrm{~kg} \mathrm{ha}^{-1}\right)$ and thousand kernel weight $(1.75 \mathrm{~g})$. Low seeds yields of the tested genotypes are questioning the cost-effectiveness of red clover seed production at this site.

Key words: Genotype, Germination, Red clover (Trifolium pratense L.), Seed yield, 1000 kernel weight.

\section{INTRODUCTION}

Alongside alfalfa, red clover (Trifolium pratense L.) is one of the most important forage legumes. Although red clover is tolerant to wetter and lower $\mathrm{pH}$ soils and less favourable weather conditions than alfalfa, it is best suited where summer temperatures are moderately cool to warm and soil moisture is available throughout the growing season (Wang et al., 2010). It is grown on about 20 million hectares worldwide. Grain yield of red clover are highly variable and range from 200 to $800 \mathrm{~kg} \mathrm{ha}^{-1}$, while the potential grain yield is over $1000 \mathrm{~kg} \mathrm{ha}^{-1}$ (Vasiljevic et al., 2005). In commercial production rarely is realized 50 per cent of the potential grain yield (Wang et al., 2010).

Thousand kernels weight is the weight of air-dried and not damaged grains. Grains with higher thousand kernels weight ensure better emergence of genotype. In cereals thousand kernels weight is a final component of grain yield and depends on many components of development in the previous phases of ontogenesis (Pržulj and Momčilovic, 2011). It is possible to influence the thousand kernels weight by agro-ecological conditions, measures of growing such as date and quality of sowing, mineral fertilizers and irrigation.

Properties of seed vitality in terms of germination energy and final germination have a direct role and are the key factor in determining plant number per hectare. In seed production it is very important to obtain seeds of high quality that have good physiological and biochemical characteristics (Boller et al., 2010). Germination percentage of different seed coat colour of red clover significantly varied (Atis et al., 2011). Brown collared seed had the lowest final germination percentage $(72 \%)$ and yellow collared seed had the highest final germination (99\%) (Atis et al., 2011).

The largest part of research on red clover applies to commercial varieties (Lugic et al., 1999), and smaller part on the local population (Kölliker et al., 2003). They suggest that locally adaptable populations of red clover have a higher breeder value compared to populations from other geographical areas. The aim of this study is to determine the grain yield and seed quality of local advanced lines and commercial varieties of red clover in agro-ecological conditions of Bosnia and Herzegovina.

\section{MATERIALS AND METHODS}

Trial site and treatments: The experiment was carried out at the location Manjaèa ( $\mathrm{N}_{4}^{\circ} 39^{\prime} 57^{\prime \prime}, \mathrm{E} 17^{\circ} 00^{\prime} 24^{\prime \prime}, 527 \mathrm{~m}$ asl), close to Banja Luka city during the 2010 and 2011 growing seasons. The soil type was a pseudoglay with acid reaction (pH 5.1). Fertilizer NPK 8:20:30 was applied before sowing, providing $20 \mathrm{~kg} \mathrm{ha}^{-1}$ of nitrogen $(\mathrm{N}), 50 \mathrm{~kg} \mathrm{ha}^{-1}$ of phosphorus $\left(\mathrm{P}_{2} \mathrm{O}_{5}\right)$ and $75 \mathrm{~kg} \mathrm{ha}^{-1}$ of potassium $\left(\mathrm{K}_{2} \mathrm{O}\right)$. In February in 2011 growing season additional $30 \mathrm{~kg} \mathrm{ha}^{-1}$ of each; N, P and K, were applied. Pests and diseases were prevented or controlled by spraying recommended fungicides

*Corresponding author's e-mail: zikhan11@gmail.com

${ }^{1}$ Centar for the Development and Improvement of the Village, Banja Luka, Bosnia and Herzegovina.

${ }^{2}$ Faculty of Agriculture, University of Banja Luka, Bosnia and Herzegovina.

${ }^{3}$ Faculty of Agriculture, University of East Sarajevo, Bosnia and Herzegovina.

${ }^{4}$ Institute of Field and Vegetable Crops, Novi Sad, Serbia. 
and insecticides, and weeds were periodically removed by hand. No artificial irrigation was applied. An experiment with four advanced lines (DS-1, DS-2, DS-3 i DS-4) and four cultivars of red clover (Kolubara, Start, Nike i Viola) was conducted by randomized block design with four replications. The plots were $1.0 \mathrm{~m}$ wide and $5 \mathrm{~m}$ long, with $0.2 \mathrm{~m}$ spacing between rows. The sowing was performed on 13th of May 2010 by hand to a depth of $1.5-2 \mathrm{~cm}$, with planting rate of $17 \mathrm{~kg} \mathrm{ha}^{-1}$ (recommended rate for field scale production). The rolling was carried out after sowing.

Measurements: In the first year there was only one growth/ cut and it was used for seed production. In the second year the first growth was used for hay, and second growth for seed production. Harvesting is carried out on 3th of October 2010 and 12th of August 2011. The testing procedures of seed quality followed those laid down by international agreement (ISTA, 2003).

Statistical analysis: The MSTAT-C program (Crop \& Soil Sciences Dep., Michigan St. Univ., USA) was used to test the main effect of growth, genotype and interactions growth $x$ genotype. Duncan's Multiple Range Test - DMRT was used to determine the significance of differences between the genotypes and their ranking for levels of significance $R=0.01$.

The AMMI model was used to assess the $\mathrm{G} \times \mathrm{E}$ interaction, and it can be represented with the following formula (Gauch and Zobel, 1996):

$$
\mathrm{Y}_{\text {ger }}=\mu+\alpha_{\mathrm{g}}+\beta_{\mathrm{e}}+\sum_{\mathrm{n}} \lambda_{\mathrm{n}} \gamma_{\mathrm{gn}} \delta_{\mathrm{en}}+\rho_{\mathrm{ge}}+\varepsilon_{\text {ger }}
$$

where $\mathrm{Y}_{\mathrm{ger}}$ is the yield for the genotype $g$ in the environment $e$ the replication $\mathrm{r}$. The additive parameters are: $\mu$ - the grand mean, $a_{\mathrm{g}}-\mathrm{a} /$ the genotypic mean deviation from the grand mean, - the environmental mean deviation. The multiplicative parameters are: $\lambda_{\mathrm{n}}-$ a singular value for $\mathrm{n}$ interaction principal component axis $\mathrm{n}, \gamma_{\mathrm{gn}}$ - the genotypic eigenvector for IPCA axis $\mathrm{n}, \delta_{\mathrm{en}}$ - the eigenvector of the environment for IPCA axis $\mathrm{n}, \rho_{\mathrm{ge}}-$ a residue when not all PCA axis are included and $-\varepsilon_{\mathrm{ger}}$ the error.

Weather conditions: Weather data (air temperatures and precipitation) were obtained from a meteorological station situated at the same location where the trial took place and reported as mean month data, together with 50 year average for temperature and precipitation (Figs. 1, 2). The growing season 2010 was with temperatures higher than 50 year average (Fig. 1) and abundant precipitation during anthesis and grain filling (Fig. 2). Growing season 2011 was dry with temperatures higher in relation to 50 year average (Figs. 1, 2). Generally, in 2010 weather conditions were less favourable for red clover seed production due to extreme precipitation during grain filling and ripening. Higher temperatures in 2011 had negative effect on grain filling.

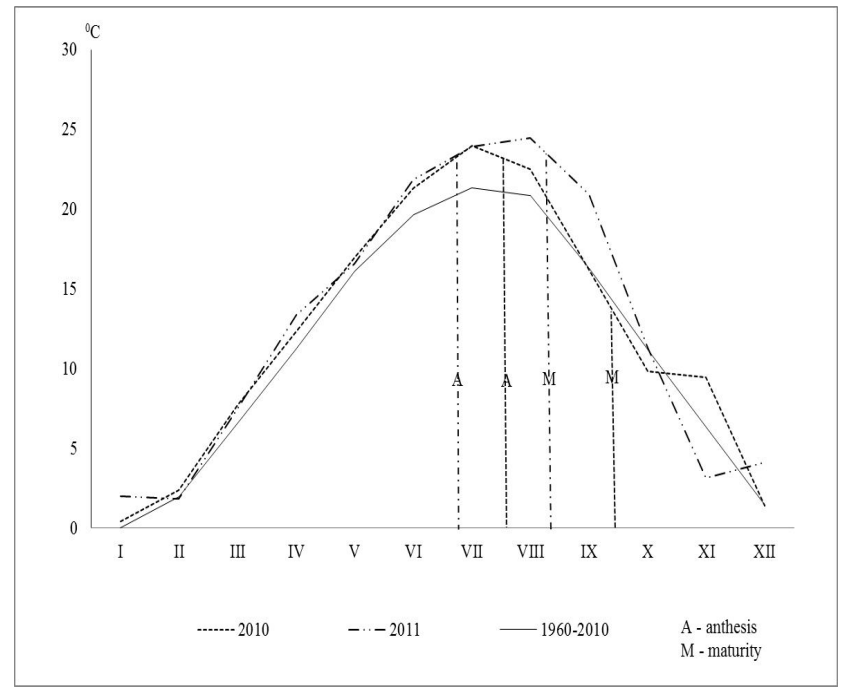

Figure 1: Average monthly temperatures in 2010 and 2011 growing seasons and long term average temperature (1960-2010).

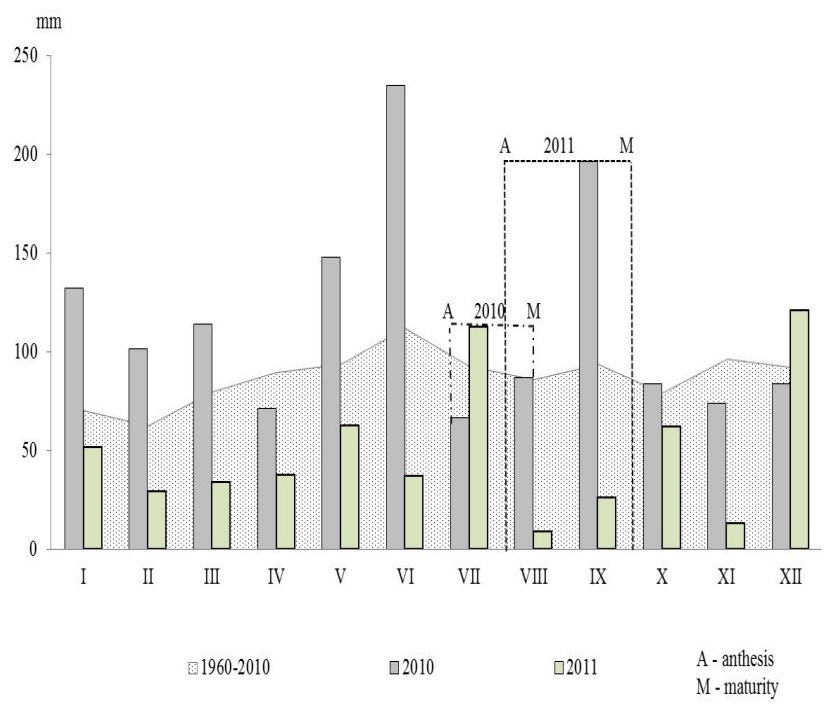

Figure 2: Average monthly precipitation for 2010 and 2011 growing seasons and long term average precipitation (1960-2010)

\section{RESULTS AND DISCUSSION}

Red clover (Trifolium pratense L.) is a high-quality; short-lived, perennial legume that is used in mixed or pure stands for pasture, hay and silage (Grabber, 2009). Stands are generally productive for two or three years, with the highest yields of hay and seed occurring in the second year, i.e. year following establishment (Boller et al., 2010; Petkoviæ et al., 2016). First year crop is able to produce seed but seed yield is lower than in second year and due to that first year crop is usually used for forage rather than for 
Table 1: Analysis of variance and percentage of variance components of seed yield, 1000-kernel weight, germination energy and final germination in eight red clover genotypes

\begin{tabular}{|c|c|c|c|c|c|}
\hline \multirow[t]{2}{*}{ Source of Variation } & \multirow[t]{2}{*}{ df } & \multicolumn{4}{|c|}{ Traits } \\
\hline & & Seed yield & 1000-kernel weight & Germination energy & Finalgermination \\
\hline Growth & 1 & $* *$ & $* *$ & $*$ & ns \\
\hline Genotype & 7 & $* *$ & $* *$ & $*$ & ns \\
\hline Growth $\mathrm{x}$ genotype & 7 & $\mathrm{~ns}$ & $\mathrm{~ns}$ & $\mathrm{~ns}$ & $\mathrm{~ns}$ \\
\hline Error & 48 & 293,99 & 1,04 & $2.4 \mathrm{E} 4$ & 369,3 \\
\hline Tottal & 64 & $2,9 \mathrm{E} 4$ & 168,9 & $2,0 \mathrm{E} 5$ & $5,2 \mathrm{E} 5$ \\
\hline \multicolumn{6}{|c|}{ components of variance $(\%)$} \\
\hline Growth & & 56.74 & 60.71 & 44.93 & 78.31 \\
\hline Genotype & & 31.24 & 30.00 & 27.28 & 3.39 \\
\hline Growth $\mathrm{x}$ genotype & & 5.49 & 1.43 & 18.61 & 7.93 \\
\hline Error & & 6.53 & 7.86 & 9.18 & 10.36 \\
\hline
\end{tabular}

$* * \mathrm{p}<0.01, * \mathrm{p}<0.05$

Table 2: Average values of seed yield $\left(\mathrm{kg} \mathrm{ha}^{-1}\right)$, thousand kernel weight $(\mathrm{g})$, germination energy $(\%)$ and final germination $(\%)$ in eight genotypes of red clover during 2010-2011.

\begin{tabular}{|c|c|c|c|c|c|c|c|c|}
\hline \multirow{2}{*}{$\begin{array}{l}\text { Genotype } \\
\text { DS-1 }\end{array}$} & \multicolumn{2}{|c|}{$\begin{array}{c}\text { Seed yield } \\
\mathrm{kg} \mathrm{ha}^{-1} \mathrm{CV}(\%)\end{array}$} & \multicolumn{2}{|c|}{$\begin{array}{l}1000 \text { kernel weight } \\
\text { CV }(\%)\end{array}$} & \multicolumn{2}{|c|}{$\begin{array}{c}\text { Germination energy } \\
\% \mathrm{CV}(\%)\end{array}$} & \multicolumn{2}{|c|}{$\begin{array}{r}\text { Final germination } \\
\% \mathrm{CV}(\%)\end{array}$} \\
\hline & $218^{\mathrm{abc}}$ & 10.07 & $1.72^{\mathrm{ab}}$ & 8.31 & $62^{\mathrm{a}}$ & 13.62 & $91^{\mathrm{a}}$ & 5.66 \\
\hline DS-2 & $234^{\mathrm{a}}$ & 13.17 & $1.75^{\mathrm{a}}$ & 7.45 & $49^{c}$ & 16.44 & $91^{\mathrm{a}}$ & 5.05 \\
\hline DS-3 & $220^{\mathrm{abc}}$ & 10.31 & $1.59^{\mathrm{ab}}$ & 8.91 & $52^{\mathrm{bc}}$ & 17.49 & $90^{\mathrm{à}}$ & 5.67 \\
\hline DS-4 & $233^{\mathrm{a}}$ & 10.4 & $1.63^{\mathrm{ab}}$ & 10.06 & $60^{\mathrm{a}}$ & 13.70 & $90^{\mathrm{à}}$ & 5.48 \\
\hline Nike & $195^{\mathrm{bc}}$ & 11.74 & $1.62^{\mathrm{ab}}$ & 10.89 & $56^{\mathrm{abc}}$ & 13.27 & $90^{\text {à }}$ & 5.80 \\
\hline Viola & $184^{\mathrm{c}}$ & 7.24 & $1.41^{\mathrm{c}}$ & 8.88 & $59^{\mathrm{ab}}$ & 16.41 & $89^{a ̀}$ & 7.26 \\
\hline Kolubara & $229^{\mathrm{ab}}$ & 16.03 & $1.57^{\mathrm{b}}$ & 8.54 & $57^{\mathrm{abc}}$ & 8.05 & $90^{\mathrm{a}}$ & 6.00 \\
\hline Start & $198^{\mathrm{abc}}$ & 15.15 & $1.63^{\mathrm{ab}}$ & 10.18 & $55^{a b c}$ & 8.44 & $90^{\text {à }}$ & 6.29 \\
\hline Average 2010 & $205^{b}$ & & $1.67^{\mathrm{a}}$ & & $54^{b}$ & & $89^{a}$ & \\
\hline Average 2011 & $223^{a}$ & & $1.56^{\mathrm{b}}$ & & $58^{\mathrm{a}}$ & & $91^{\mathrm{a}}$ & \\
\hline $\begin{array}{l}\text { Average across } \\
\text { genotype and growth }\end{array}$ & 214 & & 1.62 & & 56 & & 90 & \\
\hline \multicolumn{9}{|c|}{$\begin{array}{l}\mathrm{CV}=\text { coefficients of variability } \\
\text { a Values denoted by the same } 1\end{array}$} \\
\hline
\end{tabular}

seed. Seed production of red clover may be limited by excessive rainfall during the growing season (Gataric et al., 2010).

In our study the growth and genotype had significant influence on red clover grain yield, while the existence of interaction growth $\mathrm{x}$ genotype was not noticed (Table. 1). Grain yield was under the highest influence of growth (56.74\%), and much less influenced by the cultivars (31.24\%) indicating that climatic condition were very diverse between growing seasons. In alfalfa the year affected seed yield components markedly (Zhang et al., 2017).

Across growth the highest grain yield had advanced lines DS-2 and DS-4 and the lowest the cultivar Viola (Table. 2). All genotypes had higher grain yield in the second than in the first year (data not shown). In 2011 the highest grain yield was recorded by lines DS-2 and DS-4 and the lowest by the cultivar Viola. In the second year grain yield was slightly higher and ranged from $185 \mathrm{~kg} \mathrm{ha}^{-1}$ in the cultivar
Viola up to $256 \mathrm{~kg} \mathrm{ha}^{-1}$ in the cultivar Kolubara. Higher yield of red clover seed in the second growth of the second year compared to the first growth of the first year also found by Barac et al. (2011). AMMI1 biplot simultaneously represents main additive effect (grain yield) and the effect of the first interaction component. According to AMMI1 biplot (Fig. $3 \mathrm{a})$, there was large difference among genotypes in their IPCA1 values. Advanced lines DS-1, DS-2, DS-3 and DS-4 had higher stability compared to cultivars that were used in large scale production (Kolubara, Viola and Nike). The cultivar Start showed similar stability as advanced lines and grain yield bellow general average. The cultivar Kolubara could be separated as most unstable genotypes. Advanced lines DS-2 and DS-4 could be recommended for large scale seed production due to their higher grain yield and stability. The AMMI analysis of variance for seed yield of chickpea clearly indicates that the mean sum of square for genotypes is significant, suggesting broad range of diversity among 
genotypes (Balapure et al., 2016). In agroecological conditions of Serbia grain yield of red clover is $150-300 \mathrm{~kg}$ ha $^{-1}$ (Lugic et al., 1999). In eastern Canada grain yield up to $580 \mathrm{~kg} \mathrm{ha}^{-1}$ were released (Belzile, 1994). Exceptional low grain yields are questioning the cost-effectiveness of red clover seed production at this locality. Taylor (2008) pointed out that because of low grain yield of red clover, seed producers are reluctant to seed production of this species, even in conditions where forage yields are high.

The average grain yield across genotypes in 2010 was $205 \mathrm{~kg} \mathrm{ha}^{-1}$ and in second year, second growth $223 \mathrm{~kg}$ $\mathrm{ha}^{-1}$ (Table. 2). Lower grain yield in 2010 was result of abundant precipitation during anthesis and pollination, as well as grain filling period. Low grain yield of red clover seed due to surplus of rainfall during flowering and grain filling period found by Gataric et al. (2010). In conditions of Bosnia and Herzegovina the first growth of red clover in a season is usually removed and only the second crop is saved for seed (Petkovic et al., 2016), as we did in 2011. In some regions a prior vegetative cutting is essential for a good seed production (Lugic et al., 1999). In Check Republic grain yield are highest from stands when the first growth is cut at bud formation stage (Hejduk, 2006).

Red clover is self-sterile species and successful seed production depends on the presents of pollinators, honeybees and bumble bees. In 2010 growing season weather conditions were less favourable for pollinators' activity. Because bee activity is much greater in clear, warm, dry weather than it is in wet, cool weather, the time of greatest bloom should, if possible, coincide with the period in the summer when weather conditions are likely to be most favourable for bee activity. In 2011 growing season weather conditions were more favourable in comparison to 2010 for pollinators' activity. The yield becoming progressively less as the cutting of the first growth for hay was delayed (Hejduk, 2006).

Flower buds are developed both terminally on primary stems and on stem branches. Each contains 50-275 flowers (Asci, 2011). According to Tucak et al. (2009), thousand kernel weight in red clover depends on ploidy level, and thousand kernel weight in diploid varieties is approximately 2,1 $\mathrm{g}$ and in tetraploid 3,2-3,4 g. Seed dry weight is maximal in physiological maturity, about 4 weeks after pollination (Pe, 1978). The variability of the thousand kernel weight in our research was under the control of growth and genotypes (Table. 1). The tested genotypes did not differ in final germination (Table. 2).

Across years the highest thousand kernel weight had advanced line DS-2 (1.75 g), and the lowest had the cultivar Viola (1,41 g) (Table. 2). The highest thousand kernel weight had line DS-2 in the first growth $(1,78 \mathrm{~g})$, and the lowest had the cultivar Viola in the second growth of the second year (1,36 g) (data not shown). According to Fig. 3b, red clover genotypes had low IPCA1 values. The cultivars
Kolubara, Viola and Start had small interaction scores and similar performance across growing seasons. According to Fig. 3b genotype DS-4, DS-1, DS-2, Viola and Start would have better performance in agroecological conditions of 2011 growing season, while 2010 was more appropriate for genotypes Kolubara, DS-3 and Nike. The cultivar Nike had the lowest stability for thousand kernel weight. In the research of Atis et al. (2011) thousand kernel weight of red clover ranged from 1,712 to $1,879 \mathrm{~g}$. The thousand kernel weight in 2010 growing season across genotypes was $1,67 \mathrm{~g}$, which is for $0,11 \mathrm{~g}$ more compared to seed produced in the second growing season (Table. 2). Advanced line DS-2, that in both years had the highest thousand kernel weight, was the most stable for this trait with the lowest coefficient of variation.

Hampton and Hill (2002) point out that the decrease seed germination may be affected by adverse conditions before the harvest, as well as conditions during storage. Across genotypes germination energy was 58\% in the first and $54 \%$ in the second year (Table. 4). The highest germination energy of $64 \%$ had lines DS- 1 and DS-4 in the first growth (data not shown). Across growth the highest germination energy had lines DS- 1 and DS-4; $61 \%$ and $60 \%$, respectively, however this genotypes had the lowest stability for this trait. On the other hand, the cultivars Kolubara and Nike were the most stable (Fig. 3c). Seed germination energy can be considered as the basic criterion for germination in field conditions. If soil conditions are almost ideal germination obtained in laboratory conditions is a good indicator of its viability on which basis can be predicted field germination. Rapid germination and improved germination parameters such as germination energy enable better crops establishment by shortening the period of seed exposure to the attack of soil pathogens (Beckstead et al., 2007; Dalling et al., 2011).

The embryos of red clover seeds become viable at very early developmental stages (Pe, 1978). However, seeds can be viable but not germinable. Germination of red clover seed is complicated by the presence of hard seeds. Hard seeds fail to imbibe water within the prescribed test period (Wang and Hampton, 1989). Hard seed in legumes occurs quite promiscuously in every seed lot but varies in both degree and number from one species to another (Smýkal et al., 2014). High hard seed content in perennial legumes Centrosema pubescens can lead to delayed or decreased seedling emergence. As a result, plant stand becomes thin, sporadic and less competitive with weeds or undesirable species (Vinod et al., 2014). The development of hard seed may be due to various factors, including properties of hilum, nature of seed coat, level of seed maturity, some genetic factors and environmental conditions during seed development (Pe, 1978). In oats seed priming trough modulating water uptake and subsequent dehydration enhances the germination and field emergence (Ritu et al., 

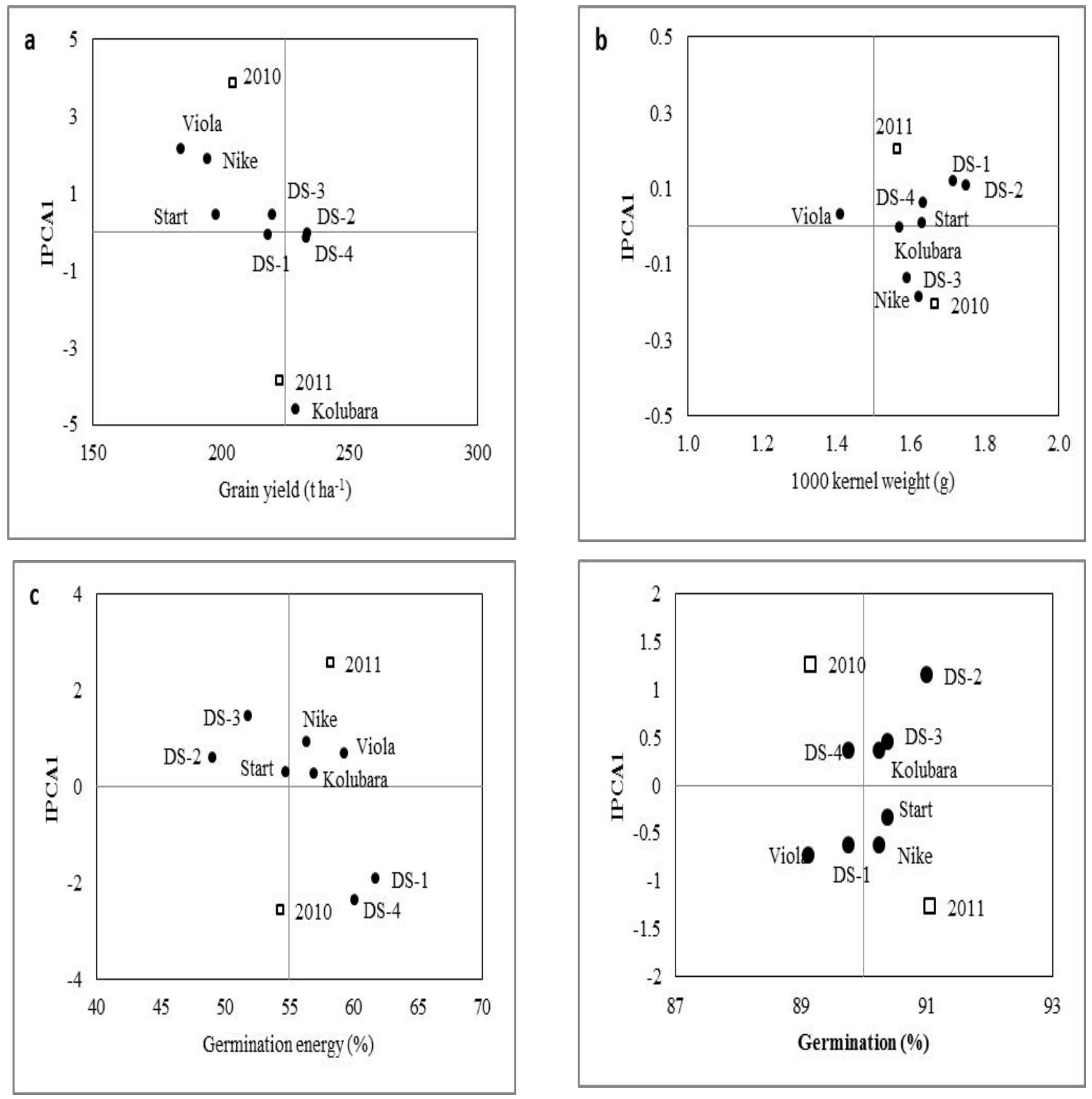

Figure 3: AMMI1 for grain yield (a), 1000 kernel weight (b), germination energy (c) and final germination (d) for 8 red clover genotypes across two growing season

2014). According to AMMI1 (Fig. 3d) biplot, the highest stability in final germination was recorded in the cultivars Start and Kolubara and advanced line DS-4. On the other hand, the cultivar Viola and line DS-2 was most unstable.

\section{CONCLUSION}

The tested genotypes of red clover were achieved a low seed yield. Across growth the highest grain yield had advanced lines DS-2 and DS-4 and the lowest the cultivar Viola. All genotypes had higher grain yield in the second than in the first year. Advanced lines DS-2 and DS-4 could be recommended for large scale seed production due to their higher grain yield and stability. Lower grain yields in 2010 were result of abundant precipitation during anthesis and pollination. The highest thousand kernel weight had advanced line DS-2 and the highest germination energy had lines DS-1 and DS-4. Low seeds yields of the tested genotypes are questioning the cost-effectiveness of red clover seed production at this site. 


\section{REFERENCES}

Asci O.O. (2011). Biodiversity in red clover (Trifolium pratense L.) collected from Turkey. I: Morpho-agronomic properties. African Journal of Biotechnology, 10: 14073-14079.

Atis A., Atak M., Can E., Mavi K. (2011). Seed Coat Clover Effects on Seed Quality and Salt Tolerance of Red Clover (Trifolium pratense). International journal of agriculture and biology, 13: 363-368.

Balapure M.M, Mhase L.B., Kute N.S., and Pawar V.Y. (2016). AMMI analysis for stability of chickpea. Legume Research, 39: 2:301-304.

Barac R., Duronic G., Karagic Đ., Vasiljevic S., Miloševic B. (2011). Effect of row spacing and seeding rate on seed and dry matter yield of red clover (Trifolium pratense L.). Field and Vegetable Crops Research, Novi Sad, 48: 155-160.

Beckstead J., Meyer S.E., Molder C.J., Smith C. (2007). A race for survival: can Bromus tectorum seeds escape Pyrenophora semeniperdacaused mortality by germinating quickly. Annals of Botany, 99: 907-914.

Belzile L. (1991). The Effect of Soil Type on Red-Clover Seed Yield. Canadian journal of plant science, 71(4): 1039-1046.

Boller B., Schubiger F.X., Kölliker R. (2010). Red Clover. Fodder Crops and Amenity, 5: 439-455.

Dalling, J.W., Davis A.S., Schutte B.J., Arnold A.E., (2011). Seed survival in soil: interacting effects of predation, dormancy and the soil microbial community. Journal of Ecology, 99: 89-95.

Gataric Đ., Kovaèevic Z., Đuric B., Radic V., Lakic Ž. (2010). Genetic resources of forage legumes and grasses in Republic of

Srpska (Bosnia and Herzegovina). Journal for the Improvement of Animal Husbandry, 26: 1-7.

Gauch H.G. and Zobel R.W. (1996). AMMI analysis of yield trials. In: Kang M.S., Gauch H.G. (eds), Genotype-by-environment Interaction. CRC Press. Boca Raton. FL: 85- 122.

Grabber J.H. (2009). Forage management effects on protein and fiber fractions, protein degradability, and dry matter yield of red clover conserved as silage. Animal Feed Science and Technology, 154: 284-291.

Hampton J.G. and Hill M.J. (2002). Seed quality and New Zeeland's native plants: an unexplored relationship? New Zeeland Journal of Botany, 40: 357-364.

Hejduk S. (2006). The persistency evaluation of Czech varieties of Red (Trifolium pratense L.) and Alsike Clover (Trifolium hybridum L.). Acta Universitatis Agriculturae et Silviculturae Mendelianae Brunensis. 54: 133-138.

ISTA (2003). Handbook on seedling evaluation, 3rd edition.

Lugic Z., Radovic J., Terzic D., Tomic Z., Spasic R. (1999). Seed production of perennial legumes in the Center of forage crops Kruševac. Plant Breeding and Seed Production, 6: 27-32.

Miloševic M., Vujakovic M., Karagic Đ. (2010). Vigour tests as indicators of seed viability. Genetika, 42: 103-118. Pe W. (1978). A study of seed development, seed coat structure and seed longevity in „Grasslands pawera” red clover (Trifolium pratense L.). Ph. thesis. Massey University. New Zealand.

Petkovic B., Gataric Đ., Radic V., Milic V., Pržulj N. (2016). Variability of yield and quality of seeds of red clover (Trifolium pratense L.). VII International Scientific Agriculture Symposium “Agrosym 2016”. 6-9.10.2016. Jahorina. Bosnia and Herzegovina.

Pržulj N., Momèilovic V. (2011). Importance of Spikelet Formation Phase in the Yield Biology of Winter Barley. Field and Vegetable Crops Research, 48: 37-48.

Ritu V., Vijay D., Gupta C.K., and Malaviya D.R. (2014). Seed quality enhancement of oat (Avena sativa L.) varieties through priming. Range Management and Agroforestry, 35: 1:2249-5231.

Smýkal P., Vernoud V., Blair W.M., Soukup A., Thompson D.R. (2014). The role of the testa during development and in establishment of dormancy of the legume seed. Frontiers in Plant Science, 2014: 5: 351.

Taylor N.L. (2008). A century of clover breeding developments in the United States. Crop Science. 48: 1-13.

Tucak M., Cupic T., Popovic S., Stjepanovic M., Gantner R., Megliè V. (2009). Agronomic evaluation and utilization of red clover (Trifoliumpratense L.) germplasm. Notulae Botanicae Horti Agrobotanici Cluj-Napoca. 37: 206 -210.

Vasiljevic S., Pataki I., Šurlan-Momirovic G., Živanovic T. (2005). Production potential and persistence of red clover varieties. Grassland Science in Europe, 10: 577-580.

Vinod K., Sridhar K., and Malaviya D.R. (2014). Overcoming the hard seededness in Centrosema pubescens seeds. Range Management and Agroforestry, 35: 1:2249-5231.

Wang Y.R., and Hampton J.G. (1989). Red clover (Trifolium pratense L.) seed quality. Proceedings Agronomy Society NZ. 19: 63-69.

Wang J., Drayton C.M., George J. (2010). Identification of genetic factors influencing salt stress tolerance in white clover (Trifolium repens L.) by QTL analysis. Theoretical and Applied Genetics. 120: 607-619.

Zhang W., Xia F., Li Y., Wang M., Mao P. (2017). Influence of year and row spacing on yield component andseed yield in Alfalfa (Medicago sativa L.). Legume Research, 40: 2:325-330. 